\title{
THERMALLy COMFORTABLE AFFORDABLE Housing: A STUDY ON RESIDENTIAL BUILDING CODE IN INDIA
}

\author{
Sneha S. Asrani ${ }^{1 *}$, Rajan U. Rawal ${ }^{1}$, Yash D. Shukla ${ }^{1}$, Peter Graham ${ }^{2}$, \\ Priyanka P. Bhanushali ${ }^{1}$, and Arjun R. Desai ${ }^{1}$ \\ 1 Centre for Advanced Research in Building Science and Energy (CARBSE), CEPT \\ University, K. L. Campus, Ahmedabad, India \\ 2 Global Buildings Performance Network (GBPN), 24 Avenue Hoche, Paris, France
}

\begin{abstract}
On average, India has more than 3000 Cooling Degree Days (CDD). The multifamily public housing being constructed under India's Prime Minister Awas Yojana (PMAY) scheme is aimed at providing formal housing to the society's Economic Weaker Section (EWS). It is essential that this housing delivers thermally comfortable indoors to the occupants. This study mapped the design and construction practices followed under PMAY Urban (PMAY-U) against India's Residential Energy Building Code, Eco Niwas Samhita (ENS). The metric prescribed in ENS is Residential Envelope Transmittance Value (RETV). For 80 PMAY-U projects, information related to spatial design, and walling assemblies were collated. 30 projects were short-listed for detailed analysis. The RETV for selected projects was calculated. The analysis demonstrated that walling assemblies and technologies having a lower thermal transmittance value (U-value) resulted in meeting the ENS code-compliant RETV number. The study further extended to assess the energy performance of the housing unit by exploring the change in walling assemblies. The dwelling unit's thermally comfortable hours and Energy Performance Index (EPI) were reported to vary between 4145 and 6034, and $64 \mathrm{kWh} / \mathrm{m}^{2}$ year and 68 $\mathrm{kWh} / \mathrm{m}^{2}$ year respectively.
\end{abstract}

Keywords: Adaptive Thermal Comfort; Affordable Housing; Eco Niwas Samhita, ECBC - R, PMAY - U; Residential Building Code.

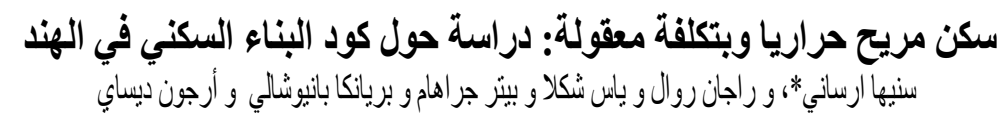

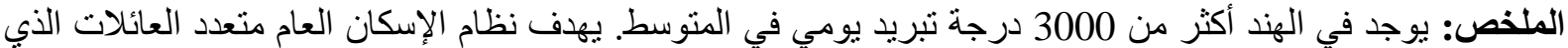

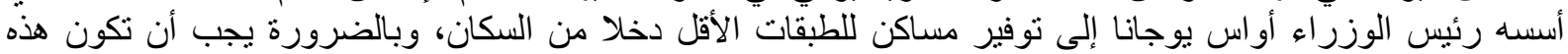

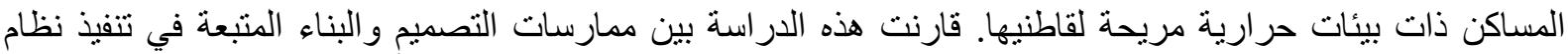

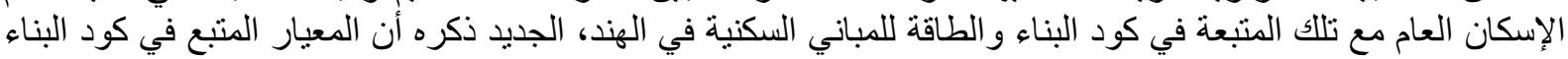

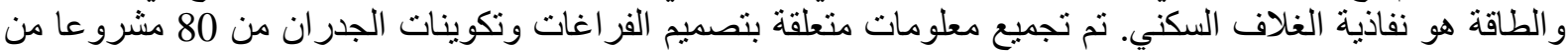

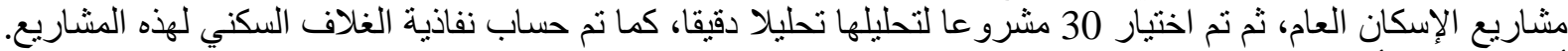

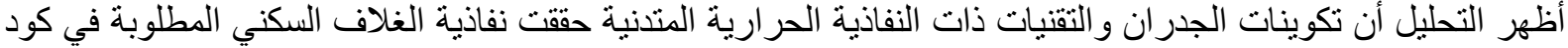

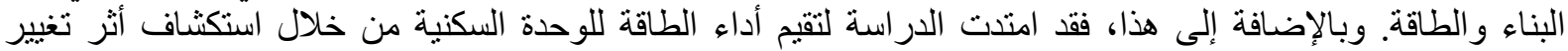

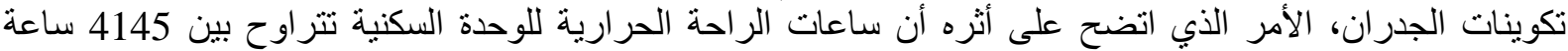

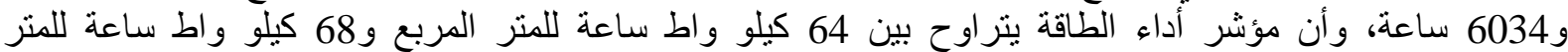
المربع.

الكلمات المفتاحية: الر احة الحرارية التكيفية؛ السكن بأسعار معقولة؛ كود البناء السكني. 


\section{NOMENCLATURE}

$\begin{array}{ll}\text { RETV } & \begin{array}{l}\text { Residential Envelope Transmittance } \\ \text { Value of the building envelope }\left(\mathrm{W} / \mathrm{m}^{2}\right) .\end{array} \\ \text { SHGC } & \begin{array}{l}\text { Solar Heat Gain Coefficient. } \\ \text { Thermal transmittance value of the wall } \\ \text { U-wall } \\ \left(\mathrm{W} / \mathrm{m}^{2} \mathrm{~K}\right) .\end{array} \\ \text { U-roof } & \begin{array}{l}\text { Thermal transmittance value of the roof } \\ \left(\mathrm{W} / \mathrm{m}^{2} \mathrm{~K}\right) .\end{array} \\ \text { WFR } & \begin{array}{l}\text { Window to Floor ratio. } \\ \omega_{i}\end{array} \\ \begin{array}{l}\text { Orientation factor of opaque/non-opaque } \\ \text { building envelope components. }\end{array} \\ \mathrm{T}_{\mathrm{op}} & \begin{array}{l}\text { Operative temperature }\left({ }^{\circ} \mathrm{C}\right) .\end{array}\end{array}$

\section{INTRODUCTION}

The building envelope's thermal characteristics play a significant role in achieving thermal comfort, reducing the energy demand and consumption. Reliance on mechanical systems to achieve thermal comfort impacts the environment negatively. The electricity consumption owing to the use of air conditioning systems and fans accounts for approximately $20 \%$ of the total electricity used in buildings, across the globe (International Energy Agency, 2018). The combined negative environmental impact of the increasing built-up area and frivolously energy-consuming buildings necessitates a building envelope that provides comfortable indoors throughout harsh outdoor conditions, without much use of electricity. India has more than 3000 Cooling Degree Days (CDD). Metropolitan cities, especially the ones having HotDry or Warm-Humid climate (Figure 1 [a]), are the worst affected; e.g., Ahmedabad having Hot-Dry climate has 3514 CDD, Mumbai and Kolkata having Warm-Humid climate have 3386 and 3211 CDD, respectively, and Delhi and Hyderabad having Composite climate have 2881 and 3221 CDD, respectively (Sivak, 2009). Such high prevalence of CDD expands the growth potential of mechanical cooling and ventilation - primarily room Air Conditioners (AC), to achieve a comfortable indoor environment (Somvanshi, 2019). This would lead to a rise in residential energy consumption, estimated to multiply by more than eight times by 2030 . However, this estimated increase can be moderated with policy and market strategies prioritizing energy efficiency (Global Buildings Performance Network, 2014).

The Indian government launched its ambitious 'Housing for All' mission in 2015. Under this mission, the Prime Minister Awas Yojana Urban (PMAY-U) scheme aimed to address the urban housing shortage among Economically Weaker Section (EWS), Low-Income group (LIG), and Middle-Income Group (MIG). As part of the program, approximately 11.30 million houses have been approved, and 5.1 million have been constructed so far. This has attracted an investment of USD 100.26 Billion, out of which USD 14.86 billion have already been released as government assistance (PMAY (U), 2021). India's Bureau of Energy Efficiency (BEE) launched the voluntary Energy Conservation Building Code-Residential (ECBC-R), also called Eco Niwas Samhita (ENS), in 2018. It adopts a variation of Over All Thermal Transfer Value (OTTV) (Rawal, et al., 2018; Saidur, et al., 2009) called, Residential Envelope Transmittance Value (RETV). RETV determines a building envelope's performance based on the thermal transmittance of the walling (U-value) and roofing assembly (U-roof), Solar Heat Gain Coefficient (SHGC), and Solar Reflectance Index.

This paper presents a study aimed at understanding the feasibility of applying ENS to PMAY-U projects, bridging the gap between the 'what is' - the prescribed measures for code compliance, to the 'how to' - steps involved in assessing code compliance. Moreover, the study was specifically aimed at perceiving the implication of various walling technologies in achieving ENS compliance. The study focused on the Affordable Housing Projects (AHP) component of the PMAY-U scheme developed under a partnership between government and private real estate developers. While other studies did attempt to evaluate a residential building's thermal performance using RETV, but these efforts were limited to either one building or a maximum of two climate zones (Agarwal \& Samuelson, 2021; Kumar et al., 2021); walling assemblies used in affordable housing construction and their impact on the indoor environment has also been studied separately (Bardhan \& Debnath, 2018; Sen et al., 2014). This study simultaneously encompasses several building envelopes across all climate zones, variations in walling assembly, and energy simulations.

\section{METHODOLOGY}

National Building Code (NBC, 2016) and Energy Conservation Building Code (BEE, 2018) have divided India into five climate zones namely Hot-Dry, Warm-Humid, Temperate, Composite, and Cold. As a first step, information of various PMAY-U projects was retrieved from secondary sources - i.e., public domain government websites (Government of Rajasthan, Local Self Government Department 2018; Govt. of Himachal Pradesh, Directorate of Urban Development 2014; Govt. of India, BMTPC n.d.; Govt. of India, Ministry of Housing and Urban Affairs 2018; Govt. of India, Ministry of Housing and Urban Affairs 2018; Govt. of Jharkhand, Urban Development \& Housing Department 2019; Govt. of Karnataka, Karnataka Slum Development Board 2016; Govt. of Maharashtra 2016; Govt. of Maharashtra 2017; Govt. of Maharashtra 2018; Govt. of Maharashtra 2019a; Govt. of Maharashtra 2019b; Govt. of Punjab, Punjab Urban Development Authority n.d.; Govt. of Tamil Nadu, Tamil Nadu Slum Clearance Board 2017; MHADA n.d.; MHADA n.d.; MoHUA n.d.; Union 
Territory of Daman, Daman Municipal Council 2017; UPAVP n.d.).

An initial list of 80 projects was compiled with details related to [a] availability of the building's technical drawings, [b] construction material, [c] climate zone, and [d] status of completion. Figure 1[a] shows the distribution of those 80 projects based on their climate zone.

The initial list was filtered based on the availability of the building's technical drawings. The filtered projects, i.e., the ones for which technical drawings were available, were sampled considering the following parameters:

- Walling assembly: This type and magnitude of residential construction needs to be economical, time-bound, and have a long service life. The Building Materials \& Technology Promotion Council (BMTPC) identified and elaborated innovative walling assemblies and technologies which would not only be resource-efficient but also optimize construction time (MoHUA, 2020). Separate model projects called the Light House Projects (LHP) are aimed at understanding the intricacies of transferring such walling technologies to the field. Thus, an effort was made to capture the variety of walling assemblies and technologies.

- Climate zone: Figure 1[b] shows the distribution of sampled projects $(\mathrm{n}=30)$ based on their climate zone. This sampling criterion ensured that there was at least one project from each climate zone.
- $\quad$ Stage of construction: Projects were categorized into either of the following - [a] proposal/planning stage, [b] under construction, or [c] completely constructed. This helped in mapping out the change in building/construction material over time.

The sampling resulted in a finalized sub-list of 30 projects (hereafter known as selected projects). Each selected project consisted of one or more apartment building blocks, having an average of 6 floors (minimum 2, maximum 36). The dwelling units had a 1BHK (Bedroom Hall Kitchen) configuration, and carpet area in the range of $22.8 \mathrm{~m}^{2}$ to $55.1 \mathrm{~m}^{2}$. Figure 1 [c] shows the distribution of buildings $(n=92)$, belonging to selected projects $(n=30)$, based on their climate zone. Figure 2 mentions various walling assemblies and technologies used in the construction of selected projects. The majority of projects $(n=19)$ used conventional walling assemblies like burnt-clay and fly-ash bricks, AAC, or concrete blocks. However, the remaining projects $(n=11)$ employed innovative technologies/assemblies like Reinforced EPS core panel or Glass Fiber Reinforced Gypsum system.

The technical drawings of all selected projects were digitized to *.dwg format. The RETV of all buildings $(n=92)$ from the selected projects was calculated using the ENS Compliance check tool. The RETV formula (BEE, 2018) is as mentioned in Equation. 1:

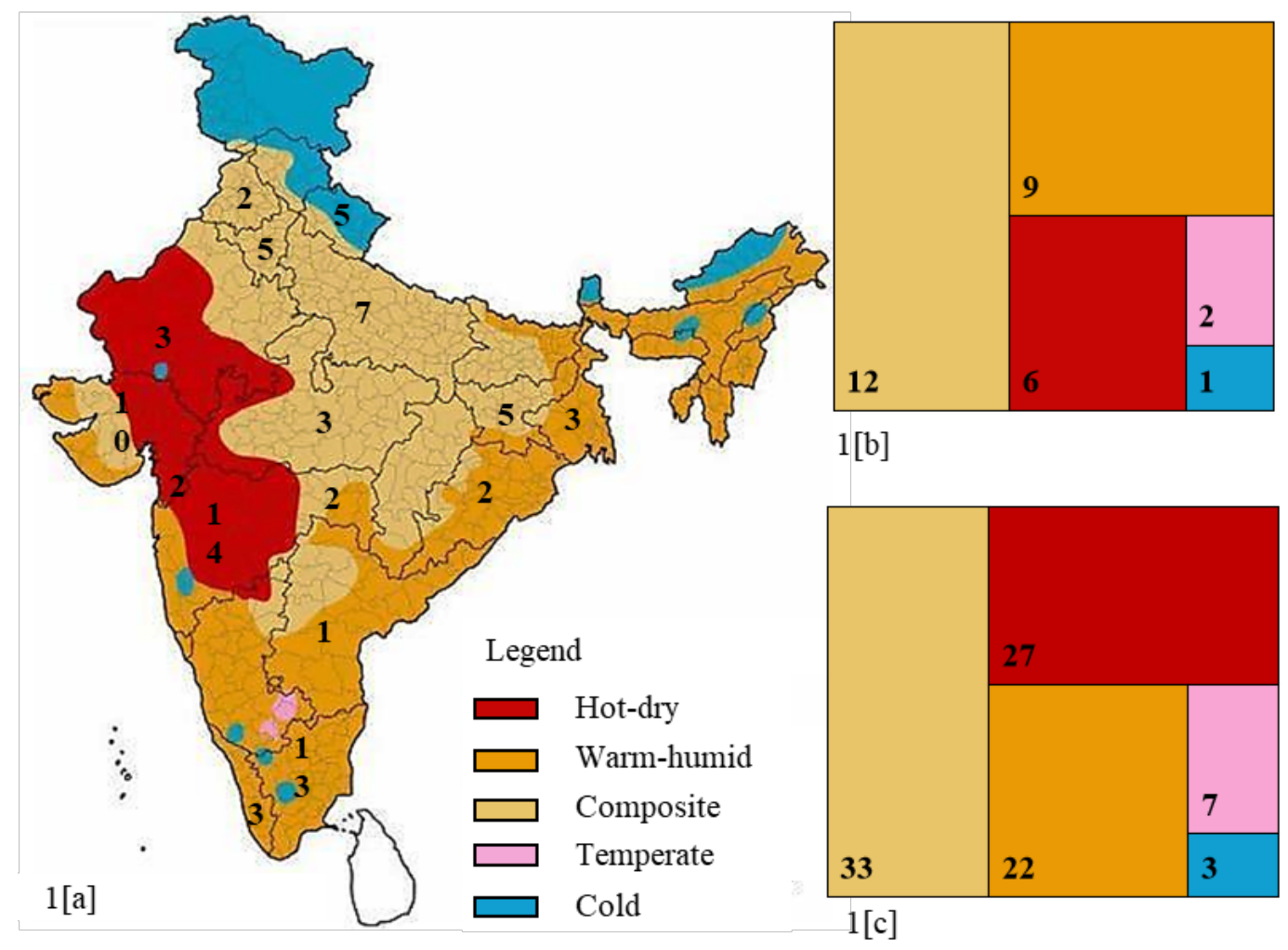

Figure 1. Distribution of - [a] 80 projects for which information was gathered, [b] selected projects $(\mathrm{n}=30)$, [c] buildings from selected projects ( $\mathrm{n}=92)$ - as per climate zone. 


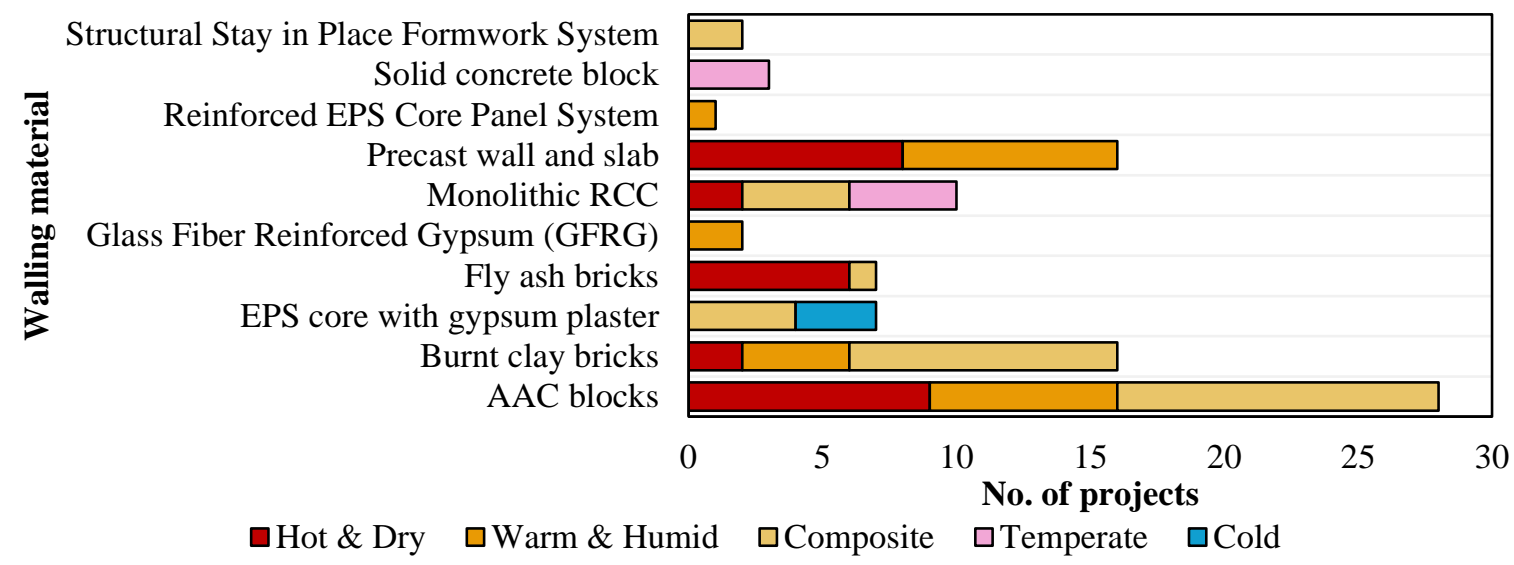

Figure 2. Distribution of selected projects based on walling assembly.

$$
\begin{aligned}
R E T V= & \frac{1}{A_{\text {envelope }}} \times\left\{\left[a \times \sum_{i=1}^{n}\left(A_{\text {opaque }_{i}} \times U_{\text {opaque }_{i}} \times \omega_{i} \omega_{i}\right)\right]+\left[b \times \sum_{i=1}^{n}\left(A_{\text {non-opaque }_{i}} \times\right.\right.\right. \\
& \left.\left.\left.U_{\text {non-opaque }_{i}} \times \omega_{i}\right)\right]+\left[c \times \sum_{i=1}^{n}\left(A_{\text {non-opaque }_{i}} \times S H G C_{\text {eq }} \times\right)\right]\right\}
\end{aligned}
$$

- $A_{\text {envelope }}$ : Envelope area (excluding the roof) of dwelling units $\left(\mathrm{m}^{2}\right)$. It is the gross external wall area including the area of the walls and the openings such as windows and doors.

- $A_{\text {opaque }_{i}}$ and $A_{\text {non-opaque }_{i}}$ : Areas of different opaque and non-opaque building envelope components, respectively $\left(\mathrm{m}^{2}\right)$

- Upaque $_{i}$ and $U_{\text {non-opaque }_{i}}$ : Thermal transmittance of different opaque and non-opaque building envelope components $\left(\mathrm{W} / \mathrm{m}^{2} \mathrm{~K}\right)$

- $S H G C_{\text {eqi }}$ : Equivalent solar heat gain coefficient values of different non-opaque building envelope components

- $\omega_{i}$ : orientation factor of respective opaque and non-opaque building envelope components; it is a measure of the amount of direct and diffused solar radiation that is received on the vertical surface in a specific orientation

For each of the buildings, the dimensions and Uvalue of the walling and roofing assembly, and dimensions of windows, doors, ventilators, and their overhangs were input manually into the tool, which in turn returned RETV, Window to Floor ratio (WFR), and U-roof as output parameters. Table 1 give the compliance values for output parameters. Note that only the walling assembly's U-value was taken into account for RETV calculation, while the U-roof was returned as an independent output parameter. Previous studies mention that for low-rise buildings the roofing assembly's impact on heat transfer is more significant than that of the walling assembly (Al-Tamimi, 2021). However, this study chose to only study the influence of the walling assembly's heat gain on the building envelope, owing to the following reasons:

- A typical PMAY-U building was mid-rise, having 6 floors.

- Innovation and variation in construction materials and assemblies across the nation.

- The ENS code only takes the walling material's U-value into account for RETV calculation. The U-roof has been prescribed to be limited to 1.2 $\mathrm{W} / \mathrm{m}^{2} \mathrm{~K}$, to reduce heat gain from the roof.

This study assessed the change in a case-study building's energy performance corresponding to the change in its walling assembly. Figures 3, 4, and 5 illustrate the unit, and floor plan, and section of the building situated in Ahmedabad's Hot-Dry climate; the building had 14 floors, having 16 dwelling units (carpet area: $27.2 \mathrm{~m}^{2}$ ) on each floor, and using fly-ash bricks as walling material. Figures 6 , and 7 establish various conventionally (' $A$ ' to ' $F$ ') and nonconventionally (' $G$ ' to ' $R$ ') used walling assemblies, and their nomenclature, i.e., W_ID. The U-values of these walling assemblies (except ' $A$ ' and ' $B$ ') were referred from Rawal, et al.’s study (2020) and can be seen in Fig. 11.

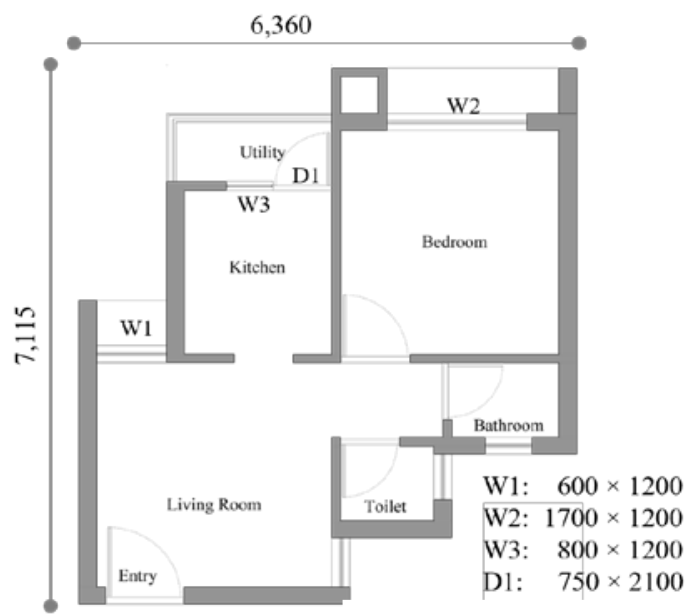

All dimensions are in $\mathrm{mm}$

Figure 3. Case-study dwelling unit plan. 
Table 1. ENS Compliance limits.

\begin{tabular}{llllll}
\hline ParameterlClimate & Hot-Dry & Warm-Humid & Composite & Temperate & Cold \\
\hline Min WFR $(\%)$ & 10 & 16.6 & 12.5 & 12.5 & 8.3 \\
Max U-roof $\left(\mathrm{W} / \mathrm{m}^{2} \mathrm{~K}\right)$ & 1.2 & 1.2 & 1.2 & 1.2 & 1.2 \\
Max RETV $\left(\mathrm{W} / \mathrm{m}^{2}\right)$ & 15 & 15 & 15 & 15 & 1.8 \\
\hline
\end{tabular}

Table 2. Electrical appliance inputs for simulation.

\begin{tabular}{llllllll}
\hline Location & Equipment & Nos. & Wattage (W) & Location & Equipment & Nos. & Wattage (W) \\
\hline Bathroom & LED light & 1 & 9 & Toilet & Incandescent bulb & 1 & 60 \\
& LED TV & 1 & 37 & Kitchen & LED light & 1 & 9 \\
Drawing & CFL bulb & 1 & 20 & & LED light & 2 & 9 \\
room & Tube light & 1 & 28 & Bedroom & Fan & 1 & 75 \\
& Fan & 1 & 75 & & & 1 & 75 \\
\hline
\end{tabular}

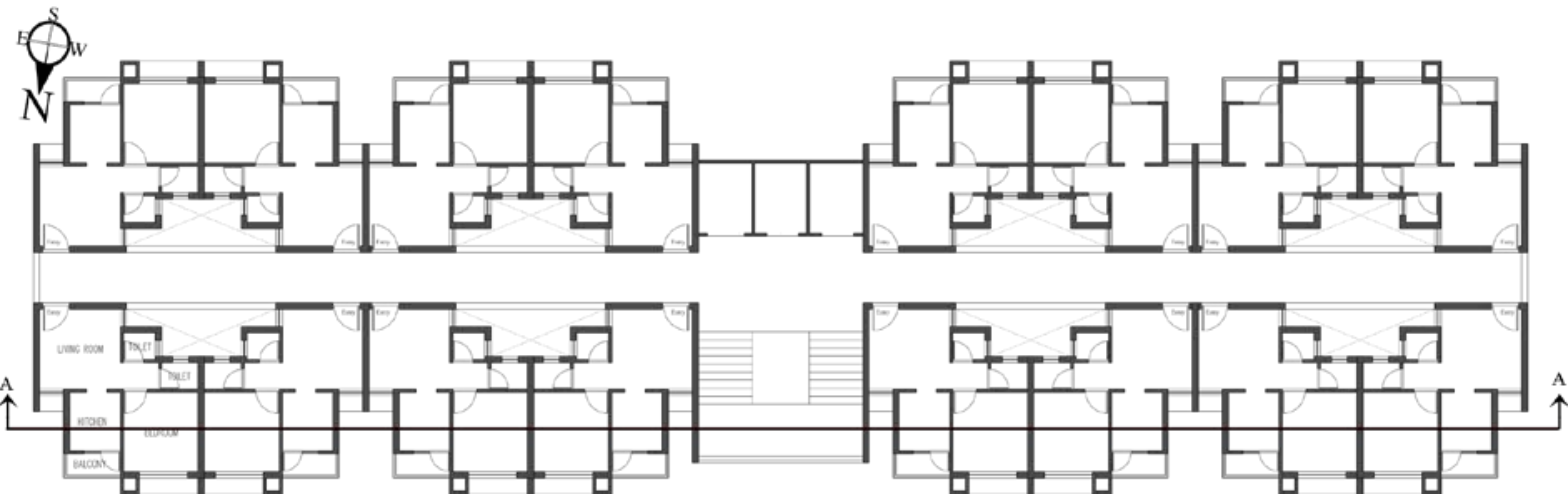

Figure 4. Floor plan of the case study.

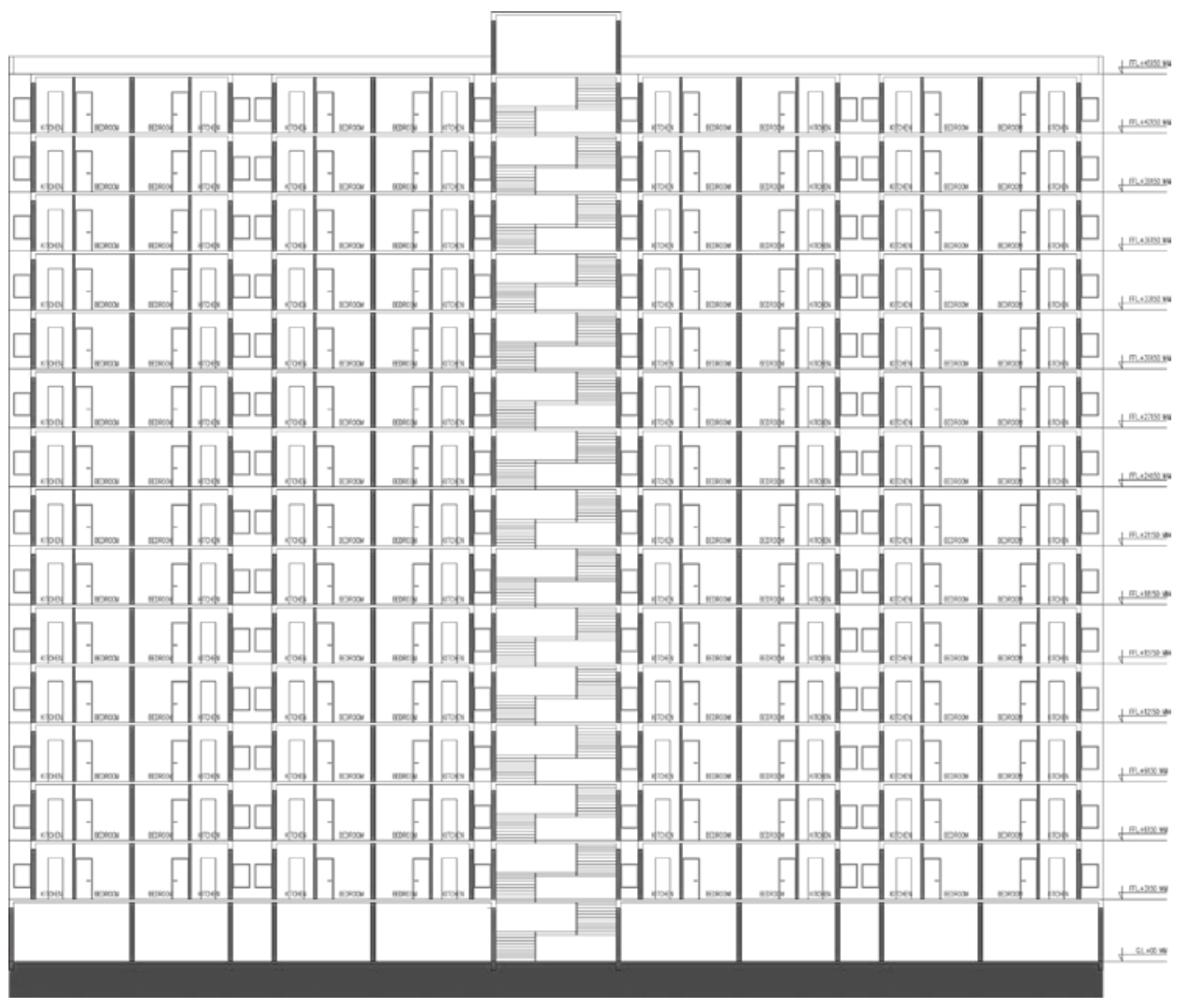

Figure 5. Section A-A of the case study. 
The building's walling assembly was sequentially changed from 'A' to 'B', 'C', 'D', till 'R', keeping other input parameters constant. The RETV corresponding to each change was calculated. Furthermore, the implication of changing the walling assembly on the building's energy efficiency was explored by conducting energy simulations, using EnergyPlus version 9.3. Here, only the walling assembly was varied, keeping all other parameters, such as roofing assembly, door, window details, etc., unchanged. The floor-to-floor height was taken to be 3 $\mathrm{m}$; the roofing assembly comprised of $4 \mathrm{~mm}$ thick ceramic glazed tiles, $50 \mathrm{~mm}$ thick cement screed, 150 mm thick RCC slab, and $15 \mathrm{~mm}$ thick internal plaster, having a resultant $\mathrm{U}$-value of $3.89 \mathrm{~W} / \mathrm{m}^{2} \mathrm{~K}$. Windows were taken to be $6 \mathrm{~mm}$ thick single glazed clear glass having a U-value of $5.8 \mathrm{~W} / \mathrm{m}^{2} \mathrm{~K}$, and SHGC 0.8. The building was taken to be operated in mixed mode, with the room split Air Conditioner (AC) being run at $28^{\circ} \mathrm{C}$ between $10 \mathrm{pm}$ and 6 am only in the bedroom, while the rest of the house was in naturally ventilated mode. The average household size was 4 - comprising 2 adults and 2 children. The electrical equipment load input can be found in Table 2. The Energy Performance Index (EPI) and thermally comfortable hours were the output of simulations. Please note that the simulation results could not be validated owing to the lack of a baseline.

\section{RESULTS}

Figure 8 shows the RETV variation across various climate zones. Referring to Table 1, Fig. 2, and Fig. 8 simultaneously, it can be observed that the RETV of most of the projects from Hot-Dry and Composite climate was non-compliant, while that of the projects from Warm-Humid, Temperate, and Cold climate was compliant. This could be attributed to the use of regionally preferred walling assemblies; assemblies used in Hot-Dry and Composite climate were found to have higher U-values, while those used in WarmHumid, Temperate, and Cold climate had relatively lower U-values (refer Fig. 11 and Fig. 8). The correlation between walling material's U-value and the envelope's RETV is seen to be established in Fig. 10. The RETV variation across various spatial orientations can be seen in Fig. 9. The mean RETV was found to be the lowest for the East-West (E-W) orientation, i.e. when the building's longer side would be parallel to the E-W axis.

The remaining output parameters of the ENS compliance tool were WFR and U-roof. The WFR for the majority of the buildings (63 out of 92) was found to be compliant with ENS; no statistically significant correlation between RETV and WFR was found. The U-roof for the majority of the buildings (89 out of 92) was found to be non-compliant with the ENS value.

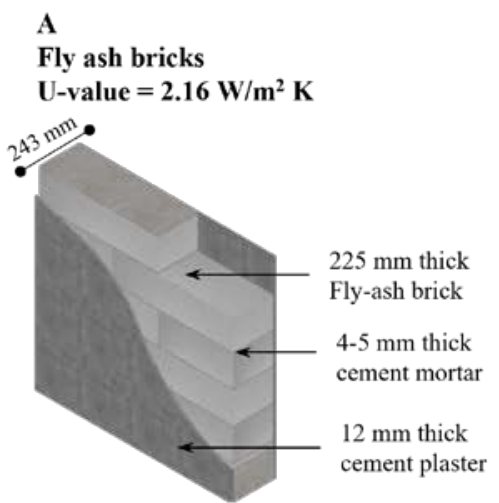

D

Light gauge framed steel structure with EPS

U-value $=1.19 \mathrm{~W} / \mathrm{m}^{2} \mathrm{~K}$

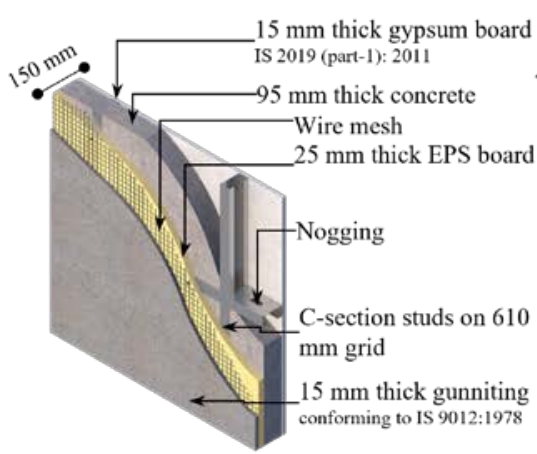

B

ENS-AAC blocks

$\mathrm{U}$-value $=0.99 \mathrm{~W} / \mathrm{m}^{2} \mathrm{~K}$

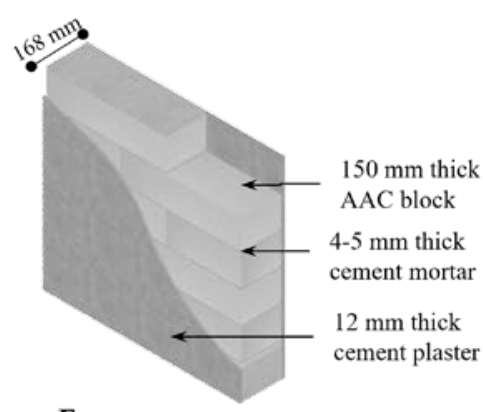

E

Light Gauge framed steel structure with PPGI Sheet $\mathrm{U}$-value $=1.63 \mathrm{~W} / \mathrm{m}^{2} \mathrm{~K}$

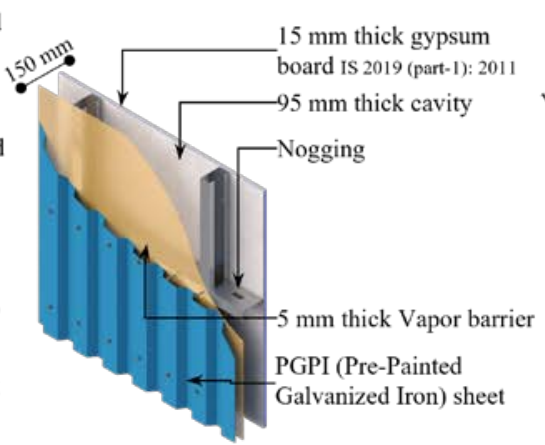

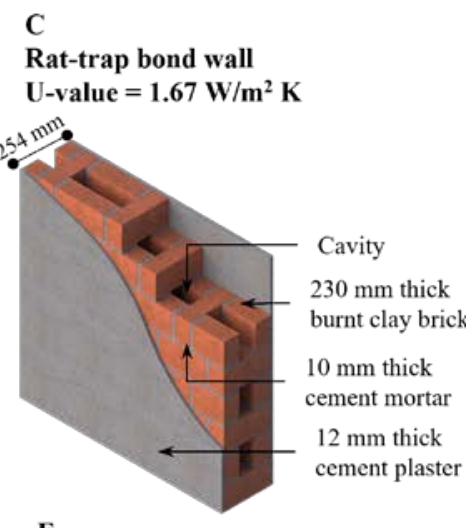

$\mathbf{F}$

Reinforced EPS core Panel system

$\mathrm{U}$-value $=0.91 \mathrm{~W} / \mathrm{m}^{2} \mathrm{~K}$

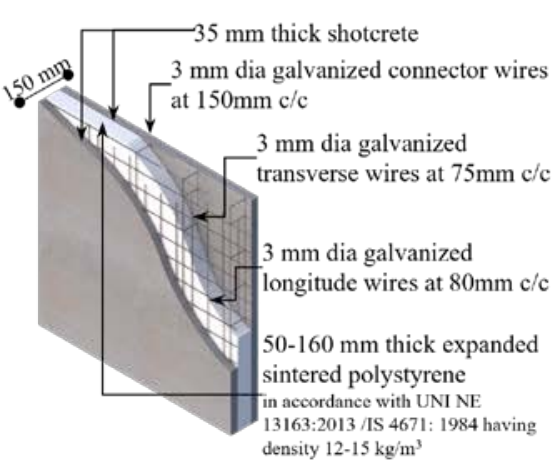

Figure 6. Walling assemblies and corresponding ID for ' $A$ ' to ' $F$ '. 


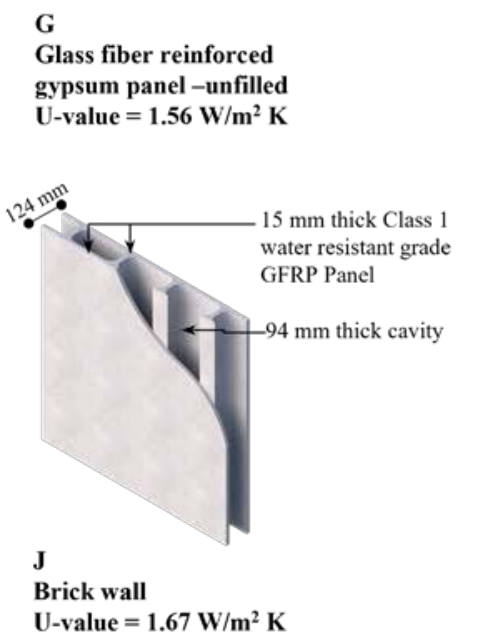

\author{
H \\ Glass fiber reinforced \\ gypsum panel -with RCC \& \\ non-structural filling \\ $\mathrm{U}$-value $=1.72 \mathrm{~W} / \mathrm{m}^{2} \mathrm{~K}$
}

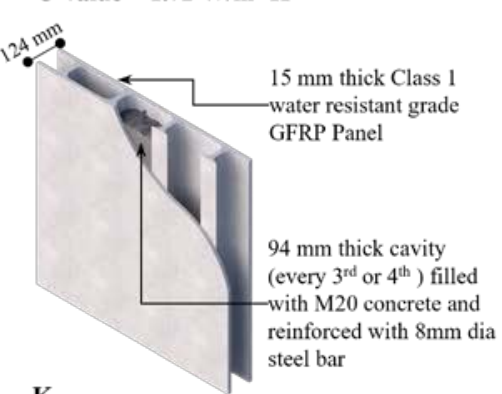

K

$\mathrm{U}$-value $=1.67 \mathrm{~W} / \mathrm{m}^{2} \mathrm{~K}$

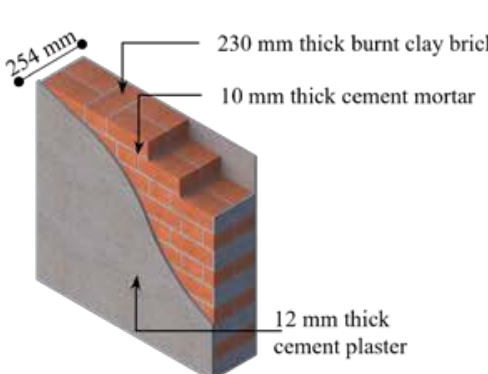

M

Stabilized adobe

U-value $=1.50 \mathrm{~W} / \mathrm{m}^{2} \mathrm{~K}$

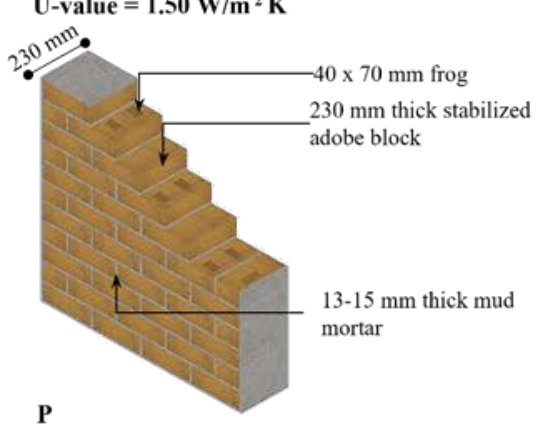

P

Compressed Stabilized Earth

block wall

$\mathrm{U}$-value $=1.59 \mathrm{~W} / \mathrm{m}^{2} \mathrm{~K}$

\section{Bamboo-crete}

$\mathrm{U}$-value $=1.82 \mathrm{~W} / \mathrm{m}^{2} \mathrm{~K}$

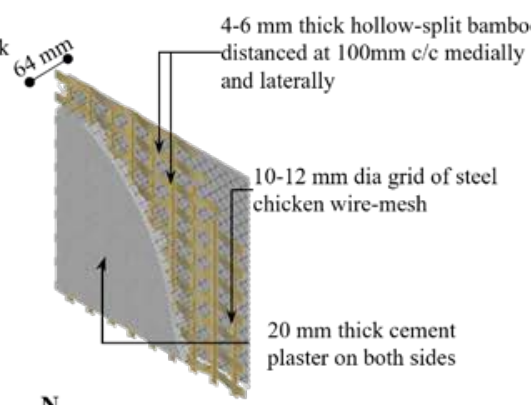

N

Laterite block wall

$\mathrm{U}$-value $=1.61 \mathrm{~W} / \mathrm{m}^{2} \mathrm{~K}$

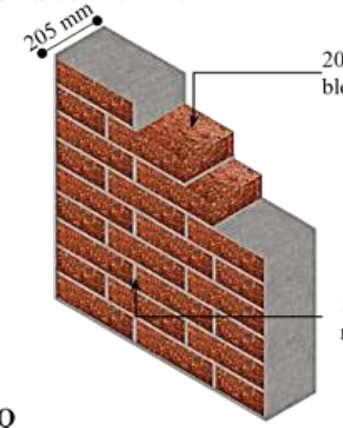

Unstabilized compressed earth

block wall

$\mathrm{U}$-value $=1.42 \mathrm{~W} / \mathrm{m}^{2} \mathrm{~K}$

\section{I}

Glass fiber reinforced gypsum panel -with partial RCC filling $\mathrm{U}$-value $=1.53 \mathrm{~W} / \mathrm{m}^{2} \mathrm{~K}$

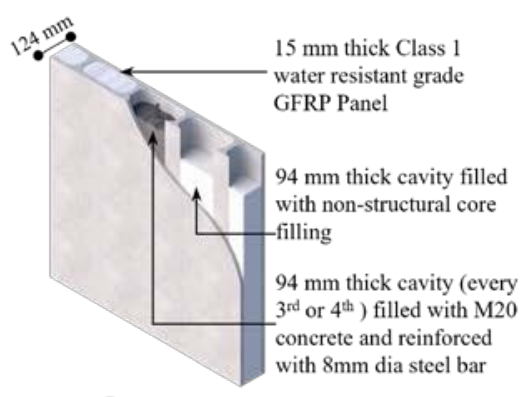

L

Wattle and daub

$\mathrm{U}$-value $=2.09 \mathrm{~W} / \mathrm{m}^{2} \mathrm{~K}$
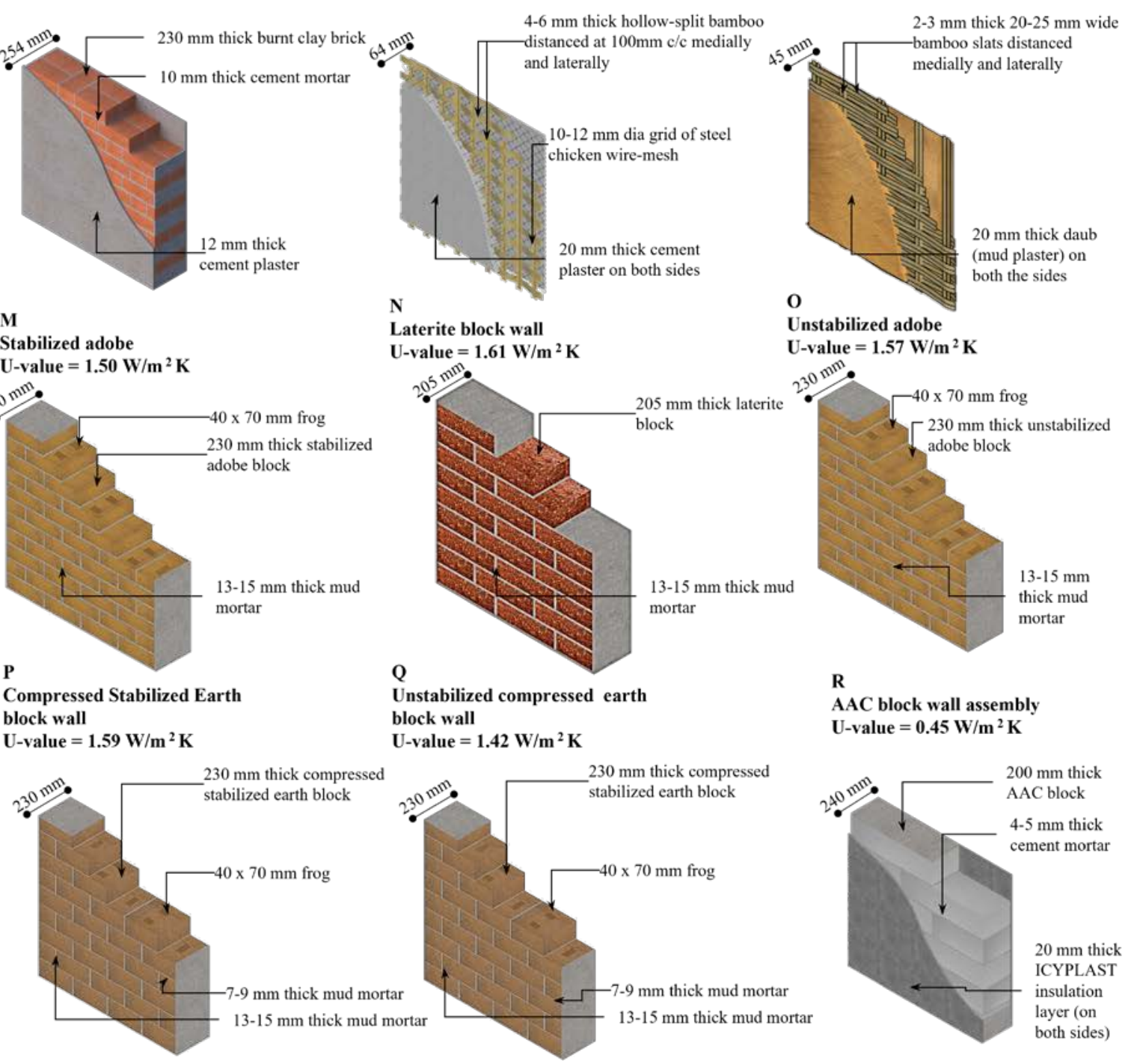

Unstabilized adobe

$\mathrm{U}$-value $=1.57 \mathrm{~W} / \mathrm{m}^{2} \mathrm{~K}$

$5 \mathrm{~mm}$ thick laterite

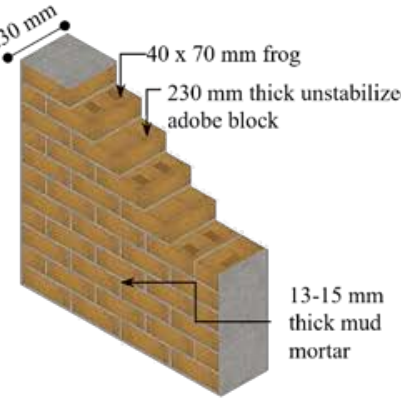

$\mathbf{R}$

AAC block wall assembly

$\mathrm{U}$-value $=0.45 \mathrm{~W} / \mathrm{m}^{2} \mathrm{~K}$

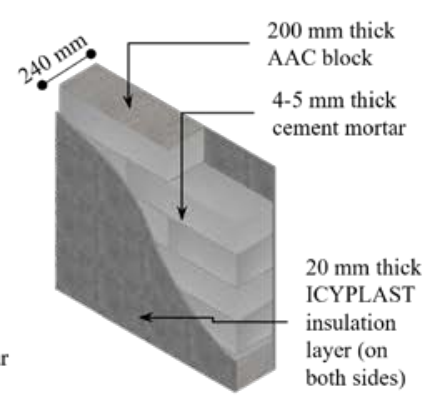

Figure 7. Walling assemblies and corresponding ID for ' $\mathrm{J}$ ' to 'R'.

Figure 11 depicts the U-value and corresponding RETV range for various walling assemblies. It can be gathered that Extruded Poly Styrene (EPS) based walling assemblies had lower U-value, hence, the RETV range was on the lower side. AAC blocks were found to have the lowest U-value and RETV amongst the conventional walling assemblies. New and innovative technologies like monolithic RCC or precast wall and slab had a relatively higher U-value and RETV.

Further on, the implication of varying the walling assembly on the building's energy performance was 
explored. The walling assembly of the case study was changed to the W_IDs mentioned in Figs. 6, and 7; the RETV corresponding to each change was calculated. The Energy Performance Index (EPI) and thermally comfortable hours (for $80 \%$ satisfaction as per IMAC 2014 Natural Ventilation model) were also derived, for each change.

Figure 12 shows the U-value and RETV for the respective alternatives. Assemblies with a lower Uvalue resulted in lower RETV. This correlation was corroborated by Fig. 10. Hi-tech walling assemblies ' $\mathrm{D}$ ' to ' $\mathrm{H}$ ' yielded RETV close to compliance value, non-conventional assemblies ' $K$ ' to ' $R$ ' performed similarly. Interestingly, both ' $B$ ' and ' $R$ ' had the same component - AAC blocks, yet the difference between their U-values was $0.54 \mathrm{~W} / \mathrm{m}^{2} \mathrm{~K}$. The ENS specified U-value of AAC blocks was used for ' $B$ '; it was the U-value of just the block. The U-value of ' $R$ ' was determined by a Guarded Hot Box experiment (Rawal. et. al., 2020); it was the resultant U-Value of the AAC blocks + heat-insulating, self-curing mortar assembly. The lowest U-value and RETV were achieved by ' $\mathrm{R}$ '.

Figure 13 illustrates the EPI and thermally comfortable hours across the walling assemblies. The non-conventional assemblies ' $K$ ' to ' $Q$ ' had relatively higher EPI than the conventional ones. The thermally comfortable hours across the assemblies ranged between 5000 and 5500 (out of 8760 hours in a year).

The innovative walling assemblies ' $D$ ' and ' $F$ ' yielded the lowest RETV and EPI while providing relatively more thermally comfortable hours. Amongst conventional assemblies, AAC blocks ('B') were found to have relatively lower RETV and EPI, and more thermally comfortable hours.

Figure 14 illustrates the range of indoor Operative Temperatures $\left(\mathrm{T}_{\mathrm{op}}\right)$ of one dwelling unit on the $2^{\text {nd }}$ floor during the day (6:00 AM to 6:00 PM) and night, across all walling assemblies. Studying Figs. 12, 13, and14 simultaneously, the $\mathrm{T}_{\text {op }}$ range across ' $\mathrm{A}$ ' to ' $\mathrm{J}$ ' is similar, with the average day Top being lower than that in the night. While ' $M$ ' to ' $R$ ' follow the opposite trend - average night $\mathrm{T}_{\text {op }}$ lower than that in the day; likely due to relatively high U-values, thus, resulting in lesser comfortable hours. Also, ' $K$ ' and ' $L$ ', having comparatively higher RETV, have a wider gap between the average day and night $\mathrm{T}_{\mathrm{op}}$.

Figure 15 shows the difference in EPI and energy consumption concerning that of the baseline (' $A$ '); Figure 16 shows the difference in equivalent $\mathrm{CO}_{2}$ emitted and its savings (\%) for all walling assemblies. Non-conventional walling assemblies (' $K$ ' to ' $R$ ' in Table 2) provided RETV close to ENS compliant value, but, resulted in higher energy consumption and $\mathrm{CO}_{2}$ release relatively. Walling assemblies having insulation ('D' to 'I') had the potential to reduce operational energy consumption and $\mathrm{CO}_{2}$ release by $2 \%$.

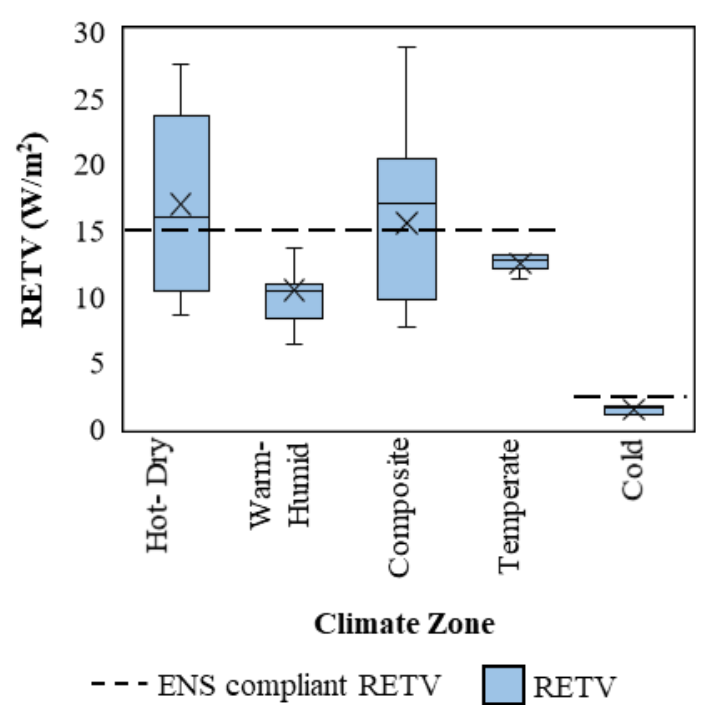

Figure 8. RETV variation across different climate zones.

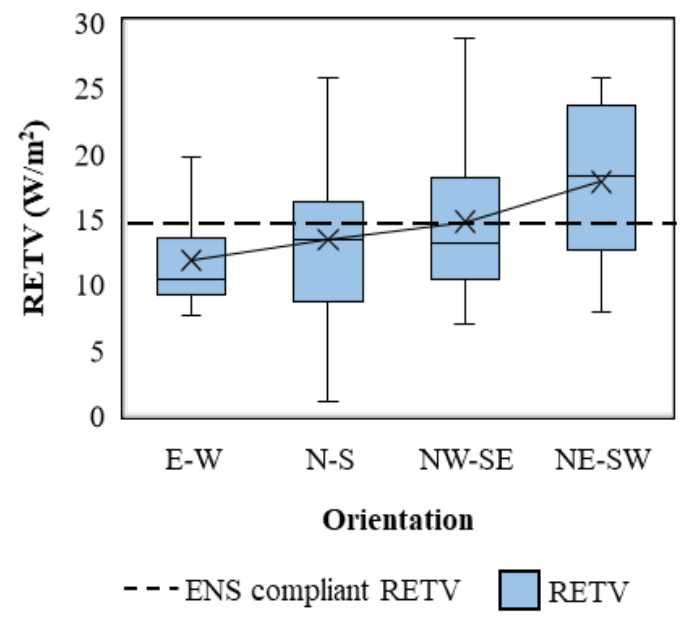

Figure 9. RETV variation across different orientations.

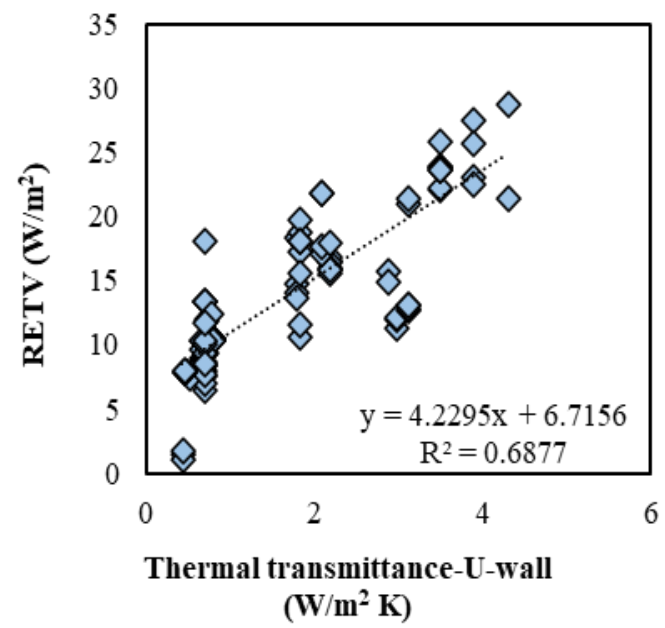

Figure 10. Correlation between U-value and RETV. 
Figure 17 depicts the compounded impact of operational energy consumption and equivalent $\mathrm{CO}_{2}$ emitted by respective assemblies, at the city (Ahmedabad, India) level. The walling assemblies with insulation (EPS or Glass fibre) - ' $\mathrm{D}$ ' to ' $\mathrm{I}$ ', required much less operational energy, thus, emitted less equivalent $\mathrm{CO}_{2}$. Amongst the conventional assemblies, AAC blocks (' $\mathrm{B}$ ' and ' $\mathrm{R}$ ') were deemed to be the best performer.

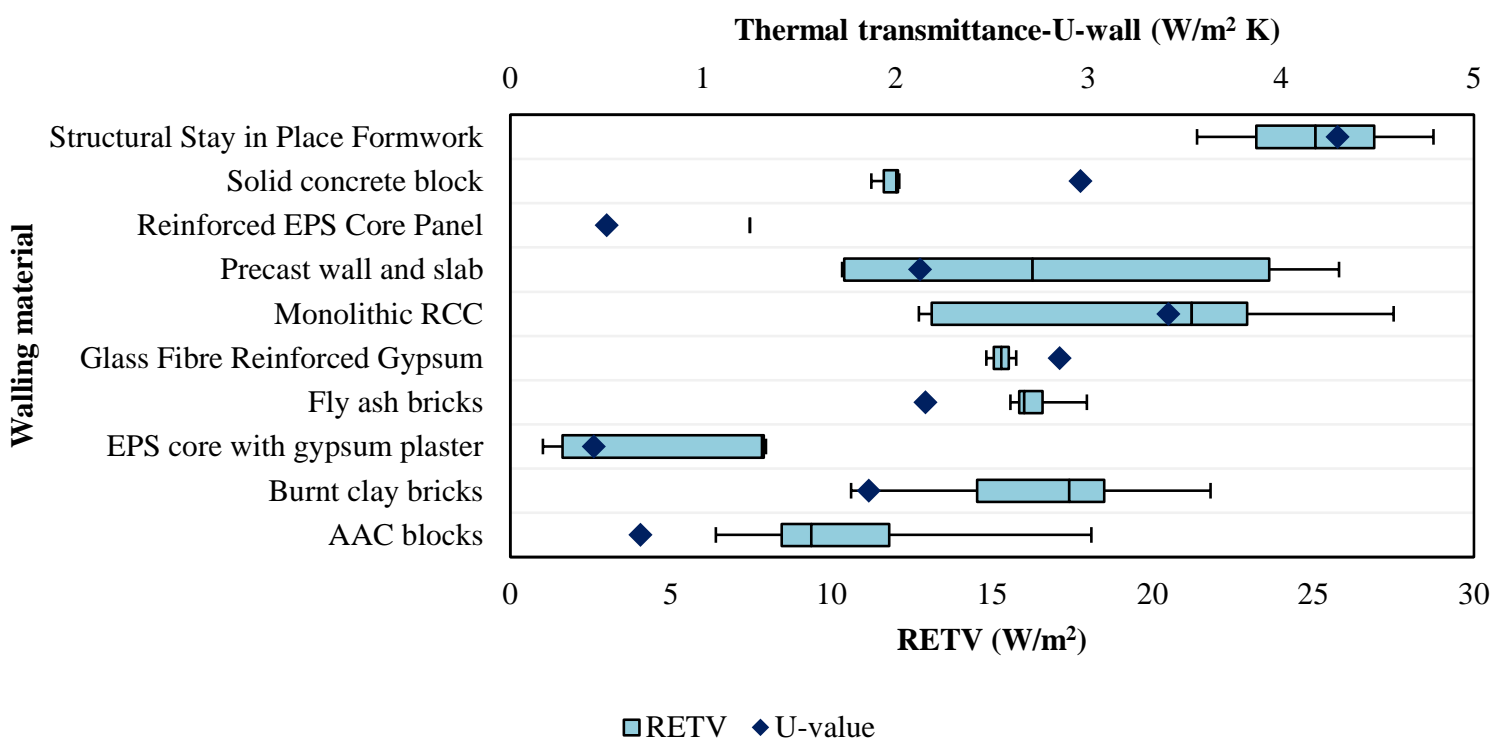

Figure 11. Variation of U-value and RETV across walling assemblies.

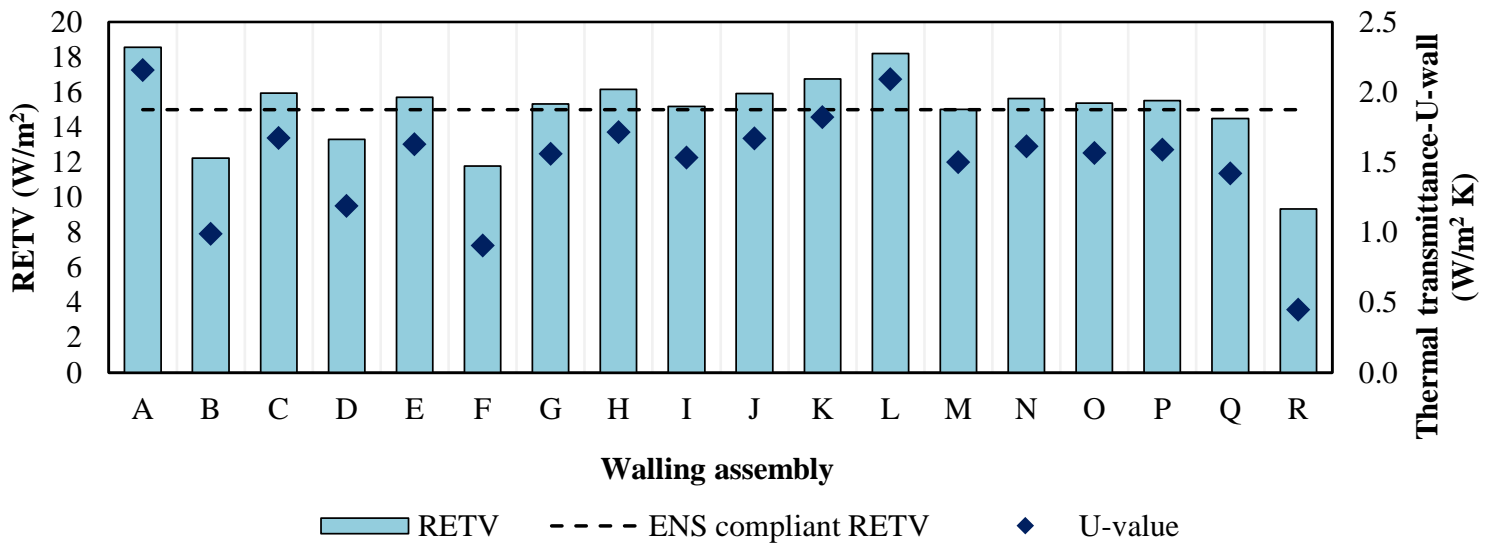

Figure 12. U-value and RETV across various walling assemblies.

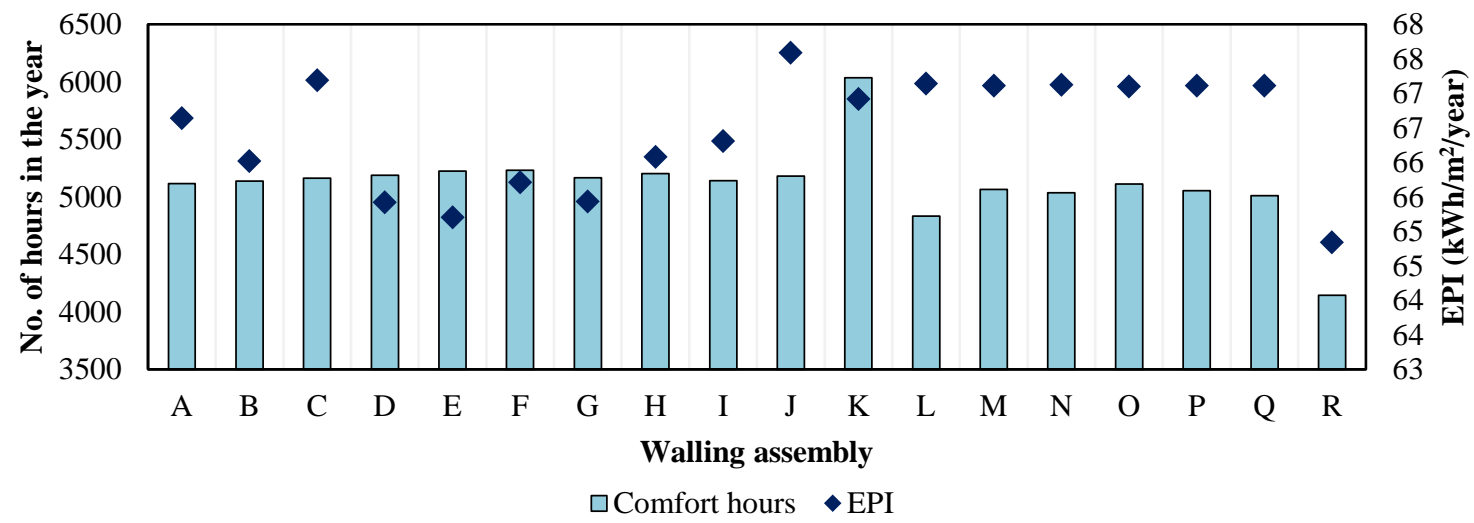

Figure 13. EPI and comfort hours across various walling assemblies. 


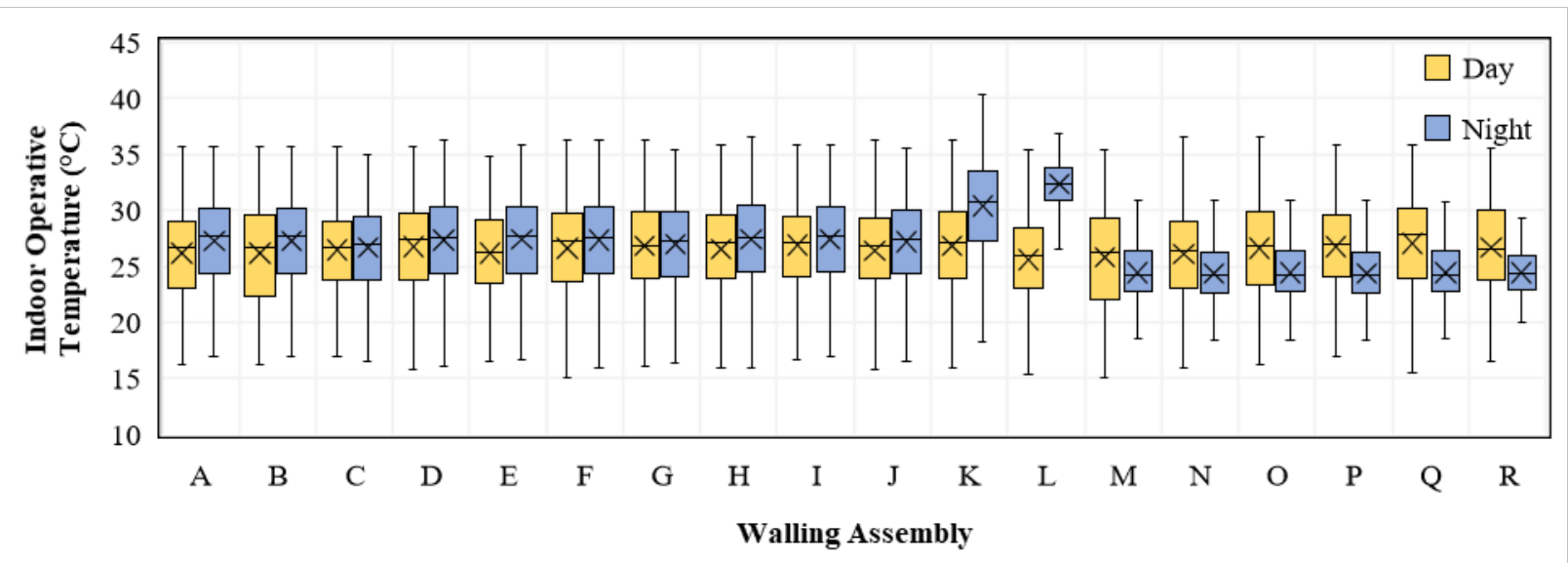

Figure 14. Range of Indoor Operative Temperature across various assemblies.

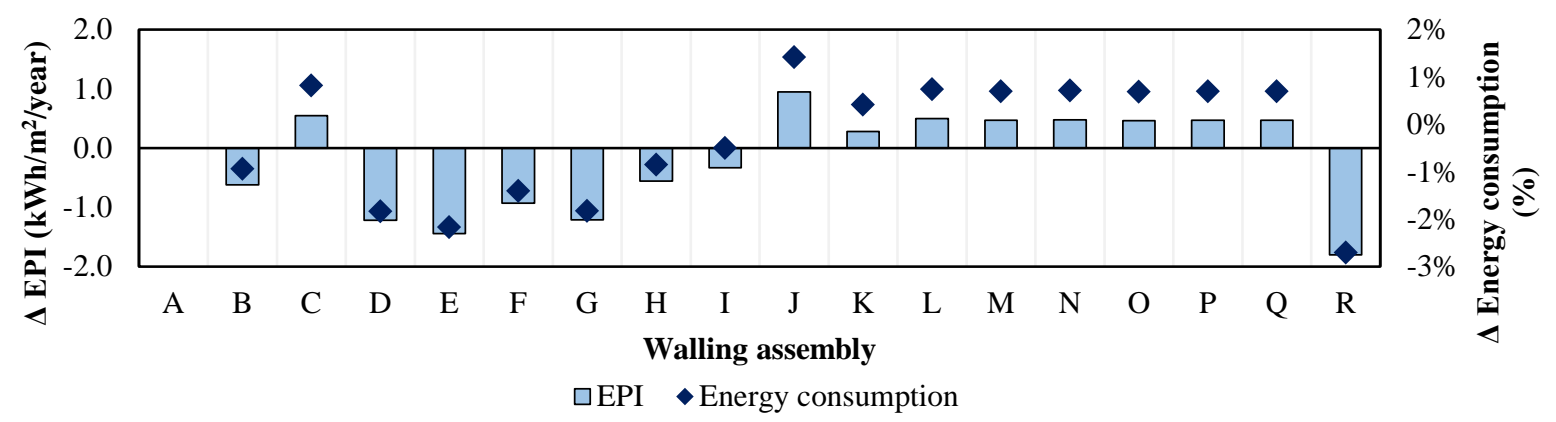

Figure 15. The difference in EPI and energy consumption across walling assemblies.

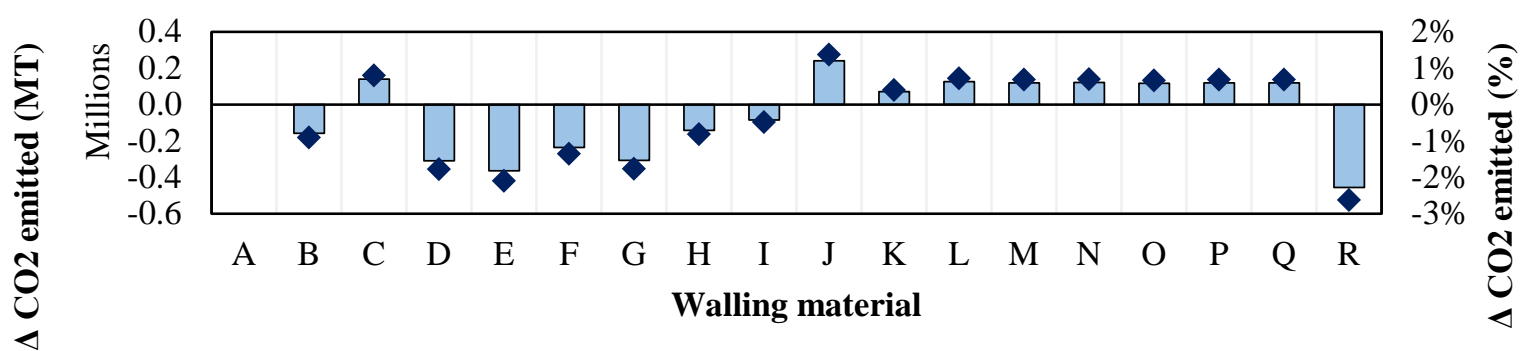

$\square \Delta \mathrm{CO} 2$ emitted (MT) $\diamond \mathrm{CO} 2$ emitted (\%)

Figure 16. The difference in Equivalent $\mathrm{CO}_{2}$ emitted and savings (\%) across various walling assemblies.

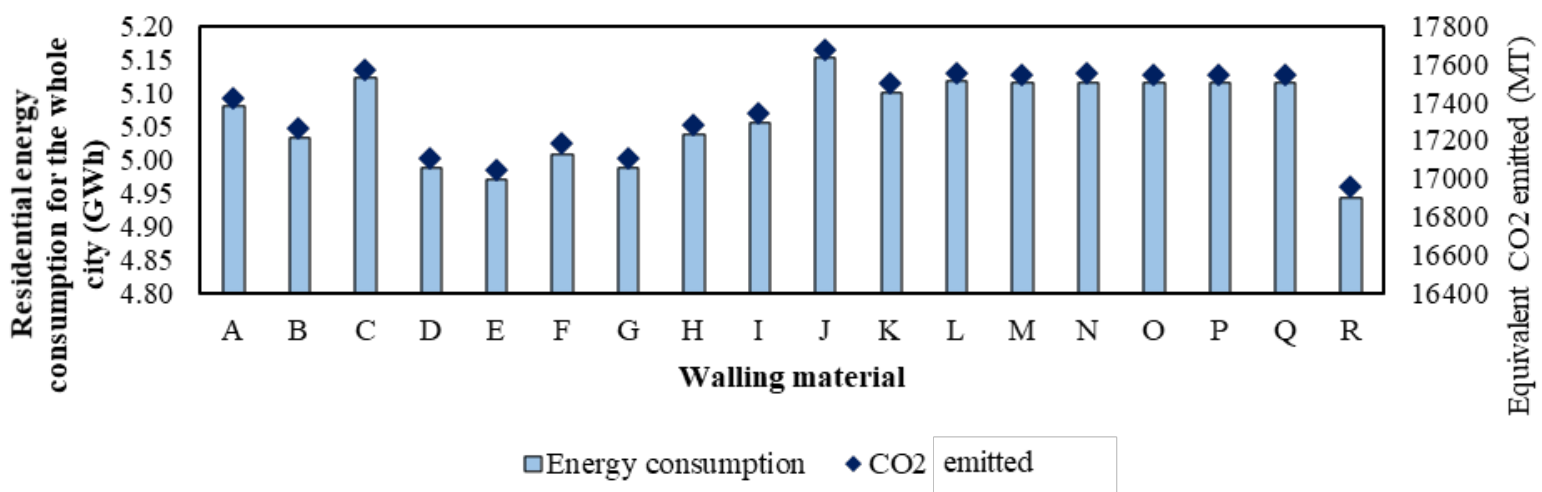

Figure 17. Energy consumption and $\mathrm{CO}_{2}$ emitted based on walling assembly - on the city level. 


\section{DISCUSSION}

The analysis showed a strong correlation between the U-value of the walling assembly and the envelope's RETV. Moreover, the mean RETV was lowest for buildings with an E-W orientation. This study brings out the following design-level simplistic, changes which could be easily implemented for significant improvement in the building's thermal performance:

- Selection of appropriate walling material or assembly: The walling material is often selected by prioritizing the speed and cost of construction, with a reduced cognizance of its thermal characteristics. Selection of walling assemblies with an insulating layer is advisable, also suggested in Bardhan \& Debnath's study. For example, constructing monolithic or precast RCC walls in a Hot-Dry climate is likely to be cost and time-efficient, but can prove to be unadvisable from the perspective of thermal performance. RCC has a higher U-value and will facilitate the inflow of excess heat into the building; however, walling assemblies with insulation, such as EPS or glass fibre, with a relatively lower U-value, would allow a significantly lower amount of heat into the building. It is also advisable to utilize thermally insulating mortars/plasters when the usage of insulation-based walling assemblies is not feasible. For example, as mentioned in Fig. 12, the walling assembly consisting of AAC blocks and a heat-insulating mortar has a U-value of $0.45 \mathrm{~W} / \mathrm{m}^{2} \mathrm{~K}$ and the lowest RETV $\left(9.35 \mathrm{~W} / \mathrm{m}^{2}\right)$, but the assembly yielded relatively higher EPI and fewer comfortable hours in comparison to the other assemblies. Therefore, it is pertinent to balance the tradeoffs between RETV, EPI, and thermal comfort. Another study highlights how optimizing the window material thickness could reduce the SHGC, thus, improve the thermal and energy performance of a building (Kumar et al., 2021).

- Optimizing building orientation: As a part of the initial building design process, assessing various building orientations and calculating their corresponding RETVs can be helpful.

- Maintaining WFR: A statistically significant correlation between RETV and WFR was not found; however, the building's WFR must comply with ENS due to its influence on the ventilation rate.

- Providing appropriate roofing insulation: As mentioned in Section 3, the U-roof for most of the projects was non-compliant with the ENSspecified value. Even though the U-roof is not considered for the RETV calculation, a higher Uroof can lead to uncomfortable thermal conditions on the top floor, also suggested in Indraganti's study.
Another study (Agarwal \& Samuelson, 2021) underlined how the ENS does not provide insights into the building envelope performance based on regional climatic context.

\section{CONCLUSION}

This study provides insight into the PMAY-U housing in context to the residential energy building code ENS. The data collection started with compiling information on 80 PMAY-U projects from secondary sources. Using filtering and sampling criteria, such as availability of technical drawings, construction material, climate zone, etc., a sub-list of 30 projects was finalized. These selected projects had one or more apartment building blocks. The RETV of all buildings was calculated using the ENS compliance tool. The analysis showed that the walling assembly's U-value and the building's orientation had a significant impact on the building's thermal performance. AAC blocks were found to have the lowest U-value and RETV. New and innovative construction technologies like precast wall and slab, and monolithic RCC had relatively higher U-value and RETV. Furthermore, the implication of a change in walling assembly on a building's thermal and energy performance was assessed by calculating the Energy Performance Index (EPI) and thermally comfortable hours. For a case study, the RETV, EPI, and thermally comfortable hours corresponding to various walling assemblies, conventional and nonconventional, were calculated. The new and innovative walling assemblies with insulation had a lower U-value, RETV, EPI, and provided relatively more comfortable hours. These assemblies had the potential to reduce the building's operational energy demand by up to $2 \%$. This $2 \%$ reduction on a building level can be amplified multifold on a city level. Hence, this study reinforces the potential of ENS code in making better-informed decisions for the design and construction of efficient buildings. The authors recommend that the thermal characteristics of the walling, roofing, and window materials be paid more consideration. Moreover, by evaluating the RETV for various orientational permutations, the thermal performance of the envelope could be optimized., in addition to improving energy efficiency, resource usage, and occupant comfort.

\section{CONFLICT OF INTEREST}

The authors declare that there is no conflict of interest.

\section{FUNDING}

Global Buildings Performance Network (GBPN) and Shakti Sustainable Energy Foundation (SSEF). 


\section{ACKNOWLEDGMENT}

The authors gratefully acknowledge the grant from Global Buildings Performance Network (GBPN).

\section{REFERENCES}

Agarwal, A., \& Samuelson, H, 2021, Too Hot to Stay at Home: Residential Heat Vulnerability in Urban India. Journal of Physics: Conference Series, 2069(1), 012166. https://doi.org/10.1088/17426596/2069/1/012166

Al-Tamimi N, 2021, An Optimum Thermal Insulation Type and Thickness for Residential Buildings in Three Different Climatic Regions of Saudi Arabia. Civil Engineering and Architecture, 9(2), 317 327. DOI: 10.13189/cea.2021.090205.

Bardhan, R., \& Debnath, R, 2018, Evaluating building material based thermal comfort of a typical lowcost modular house in India. Materials Today: Proceedings, 5(1), 311-317. https://doi.org/ 10.1016/j.matpr.2017.11.087

BEE, 2018, Energy Conservation Building Code Residential.

Government of Rajasthan, Local Self Government Department. 2018, Presentation of Rajasthan State for Sanction by Central Sanctioning \& Monitoring Committee Under Housing for All [PDF], Retrieved: 14 September, 2021, from https://pmay-urban.gov.in/uploads/ presentations /Rajasthan_CSMC.pdf

Govt. of Himachal Pradesh, Directorate of Urban Development. 2014, Invitation Of Expression Of Interest [PDF], Retrieved: 14 September, 2021 from http://bmtpc.org/DataFiles/CMS/file /PDF_Files/03_Tender_EOI_SOLAN_HPUD.pdf

Govt. of India, BMTPC. n.d., Demonstration Housing Project using Emerging Technologies [PDF], Retrieved: 14 September, 2021, from http://mohua.gov.in/upload/uploadfiles/files/1BM TPC-Demo-Housing.pdf

Govt. of India, Ministry of Housing and Urban Affairs. 2018, Annual Report, 2017-18 [PDF], Retrieved: 14 September, 2021, from http://164.100.161.188/upload/uploadfiles/files/ne w_AR-2017-18\%20(Eng)-Website.pdf

Govt. of India, Ministry of Housing and Urban Affairs. 2018, CSMC_Minutes_24-07-2018 [PDF], Retrieved: 14 September, 2021, from http://mohua.gov.in/upload/uploadfiles/files/CSM C_Minutes_24-07-2018.pdf

Govt. of Jharkhand, Urban Development \& Housing Department. 2019, Proposal for 34 projects under vertical III (AHP) [PDF], Retrieved: 14 September, 2021, from: http://mohua.gov.in /upload/uploadfiles/files/Jharkhand(1).pdf

Govt. of Karnataka, Karnataka Slum Development Board. 2016, CSMC Meeting, 11th August 2016
[PDF], Retrieved: 14 September, 2021, from http://mohua.gov.in/upload/uploadfiles/files/2csm c11KSDBppt.pdf

Govt. of Maharashtra. 2016, CSMC meeting, 22nd July 2016 [PDF], Retrieved: 14 September, 2021, from http://mohua.gov.in/upload/uploadfiles/ files /6csmc010Maharashtra.pdf

Govt. of Maharashtra. 2017, CSMC meeting 30th September 2016 [PDF], Retrieved: 14 September, 2021, from http://mohua.gov.in/upload/uploadfiles /files/4csmc013Maharashtra.pdf

Govt. of Maharashtra. 2018, CSMC meeting, 28th November 2019 [PDF], Retrieved: 14 September, 2021, from https://pmay-urban.gov.in /uploads /presentations/Maharashtra(5).pdf

Govt. of Maharashtra. 2019a, CSMC meeting, 29th August 2019 [PDF], Retrieved: 14 September, 2021, from http://mohua.gov.in/upload/ uploadfiles/files/Maharashtra_46_CSMC.pdf

Govt. of Maharashtra. 2019b, $\overline{C S M} \bar{C}$ meeting, 28th June 2019 [PDF], Retrieved: 14 September, 2021, from http://mohua.gov.in/upload/uploadfiles /files/Maharashtra(7).pdf

Govt. of Punjab, Punjab Urban Development Authority. n.d., Development Of EWS Dwelling Units At Patiala-Sangrur Road, Patiala City [PDF], Retrieved: 14 September, 2021, from https://pmay-

urban.gov.in/uploads/presentations/Punjab_CSMC .pdf

Govt. of Tamil Nadu, Tamil Nadu Slum Clearance Board. 2017, Proposal for 456 projects under vertical III \& IV [PDF], Retrieved: 14 September, 2021,

from http://mohua.gov.in/upload/uploadfiles/files/csmc 021tamilnadu.pdf

Global Buildings Performance Network. 2014, Residential Buildings in India: Energy Use Projections and Savings Potentials. Viewed -14 September 2021, <https://www.gbpn.org/wpcontent/uploads/2021/06/INFOGRAPHIE_PPT_1. pdf $>$

Indraganti, M, 2010, Using the adaptive model of thermal comfort for obtaining indoor neutral temperature: Findings from a field study in Hyderabad, India. Building and Environment, 45(3), 519-536. https://doi.org/10.1016/j.buildenv. 2009.07.006

International Energy Agency. 2018, The Future of Cooling Opportunities for energy- efficient air conditioning. Viewed - 14 September 2021, < https://www.iea.org/reports/the-future-of-cooling>

Kumar, G., Thakur, B., \& De, S, 2021, Energy performance of typical large residential apartments in Kolkata: implementing new energy conservation building codes of India. Clean Technologies and Environmental Policy, 23(4), 1251-1271. https://doi.org/10.1007/s10098-020- 
02022-7

MHADA. n.d., Mouje-Khoni, Thane. Retrieved on 14 September, 2021, from https://mhada.gov.in/en/ content/mouje-khoni-thane

MHADA. n.d., Scheme-Wanjara. Retrieved on 14 September, 2021, from https://mhada.gov.in /sites/default/files/Scheme-Wanjara.pdf

MoHUA. n.d., DPR No.1 Ray Nagar Federation, Solapur [PDF] Retrieved on 14 September, 2021, from http://mohua.gov.in /upload/ uploadfiles/ files/5Maharashtra02-09csmc.pdf

MoHUA, 2020, Compendium of Innovative Emerging Technologies shortlisted under Global Housing Technology Challenge - India.

National Building Code of India (NBC), 2016, $<$ http://www.bis.org.in/sf/nbc.htm>

Pathak A, Garg T, Kumar S, 2020. A Policy Strategy for Decarbonising the Building Sector: Facilitating ENS Implementation in Affordable Housing. Technical report, Retrieved from https://aeee.in/

PMAY (U). [online], Retrieved: 29 November, 2021, from https://pmay-urban.gov.in/.

Rawal R, Kumar D, Pandya H, Airan K, 2018, Residential Characterization. Ahmedabad: Centre for Advanced Research in Building Science and Energy. Technical report, Retrieved from: https://shaktifoundation.in/

Rawal R, Shukla Y, Shah A, Gowri G, 2020, Thermal performance of walling material and wall technology, Part-2. Technical report, Retrieved from http://carbse.org/, https://www.beepindia.org

Rawal R, Shukla Y, Bhanushali P, Desai A, Asrani S, 2021, A Policy Strategy For Decarbonizing The Building Sector: Project report- January 2021.
Technical report, Retrieved from http://carbse.org/ Roychowdhury A, Sareen R, Singh M, 2020, Beyond the four walls of PMAY: Resource efficiency, thermal comfort and liveability in the affordable housing sector. Technical report, Retrieved from http://.cseindia.org/

Sen, R., Kandra, S., \& Chattopadhyay, S, 2014, Investigation on the performance of alternative walling materials in an affordable housing unit situated in warm humid climate. 30th International PLEA Conference: Sustainable Habitat for Developing Societies: Choosing the Way Forward - Proceedings, 1(December 2014), 524-531.

Sivak M, 2009, Potential energy demand for cooling in the 50 largest metropolitan areas of the world: Implications for developing countries. Energy Policy, 37(4), 1382-1384. https://doi.org/ 10.1016/j.enpol.2008.11.031

Somvanshi A, 2019, A Midsummer Nightmare: Decoding the link between comfort, space cooling and energy consumption in a climate-stressed world. Technical report, Retrieved from http://.cseindia.org/

UPAVP. n.d., Majhola Yojana, Moradabad. Retrieved: on 14 September, 2021, from: https:/upavp.in/pmay/Majhola-yojna/

Union Territory of Daman, Daman Municipal Council. 2017, Pradhan Mantri Awas YojanaHousing For All (Urban). Retrieved: on 14 September, 2021, from http://mohua.gov.in/upload/uploadfiles/files/Dama n\%26Diu_27_csmc.pdf 